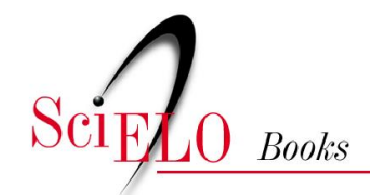

\title{
Sêneca, Montaigne e a utilidade dos saberes
}

\author{
Maria Cristina Theobaldo
}

THEOBALDO, M.C. Sêneca, Montaigne e a utilidade dos saberes. In: PINTO, F.M., and BENEVENUTO, F., comps. Filosofia, política e cosmologia: ensaios sobre o renascimento [online]. São Bernardo do Campo, SP: Editora UFABC, 2017, pp. 199-225. ISBN: 978-85-68576-93-9.

https://doi.org/10.7476/9788568576939.0011.

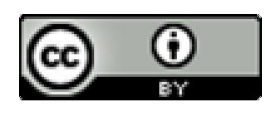

All the contents of this work, except where otherwise noted, is licensed under a Creative Commons Attribution 4.0 International license.

Todo o conteúdo deste trabalho, exceto quando houver ressalva, é publicado sob a licença Creative Commons Atribição 4.0.

Todo el contenido de esta obra, excepto donde se indique lo contrario, está bajo licencia de la licencia $\underline{\text { Creative }}$ Commons Reconocimento 4.0. 
Doutora em Filosofia pela USP. É professora do Departamento de Filosofia da Universidade Federal de Mato Grosso. Tem experiência de docência e pesquisa na área de Filosofia, com ênfase em História da Filosofia Moderna, História da Filosofia da Renascença e Ensino de Filosofia na Educação Básica. 


\title{
SÊNECA, MONTAIGNE E A UTILIDADE DOS SABERES
}

\author{
Maria Cristina Theobaldo ${ }^{1}$
}

Há ciências estéreis e espinhosas, e na maioria forjadas para as multidões: é preciso deixá-las para os que estão a serviço do mundo (MONTAIGNE, Ensaios, Livro I, 39).

No capítulo "Do pedantismo" dos Ensaios (Livro I, 25), encontramos uma passagem que ratifica exemplarmente o eixo argumentativo deste estudo, qual seja, a recepção de Sêneca no tratamento do tema da utilidade dos saberes. Montaigne escreve: "[c] Proclamai a nosso povo, sobre um passante: 'Oh, que homem sábio!' e sobre um outro: 'Oh, que homem bom!' [...] Seria preciso perguntar quem sabe melhor, e não quem sabe mais." (MONTAIGNE, 2002, p. 203). Esta é uma referência direta à Carta 88 , das Cartas a Lucílio sobre os

\footnotetext{
${ }^{1}$ Professora do Departamento de Filosofia da Universidade Federal de Mato Grosso (UFMT).
} 
estudos liberais; ali Sêneca registra: "Uma saudação como esta: 'Oh! Que homem erudito!', implica um enorme gasto de tempo e uma enorme maçadoria para os ouvidos alheios. Contentemo-nos com este mais modesto título: “Oh! Que homem de bem!" (SÊNECA, 2009, p. 427), ou sua extensão abreviada num conselho a Lucílio: "Estuda, em suma, não para saberes mais, mas para saberes melhor!" (Idem, Carta 89, p. 438). A relação entre o saber e a ética se põe claramente nestas passagens, na medida em que, implicitamente, carregam a crítica à relevância de certos saberes para a vida prática em detrimento de outros. Montaigne, sob os préstimos de Sêneca ${ }^{2}$, reconstrói a argumentação da utilidade dos saberes a partir de tópicas tradicionais, entre elas destacamos: 1. a importância dos estudos liberais e sua relação com o ajuizamento moral; 2 . a crítica às "sutilezas intelectuais", um derivativo da excessiva dedicação e do longo tempo despendido para se instruir nas artes liberais e a proporcional utilidade que podem ocasionar; e 3. a participação da filosofia na vida virtuosa.

Como sabemos, o contexto cultural e social do século XVI é marcado por recorrente instabilidade política e religiosa e por profundas transformações nos campos das ciências e das artes ${ }^{3}$. A autoridade da tradição e a emergência do novo (novos povos e culturas, novos territórios, novas técnicas etc.), antes de provocarem sínteses seguras, acirram conflitos no

\footnotetext{
2 Sobre Epicuro e Sêneca: “[...] tampouco são cartas vazias e descarnadas, que se sustentam apenas por uma delicada escolha de termos acumulados e ordenados num ritmo regular, e sim recheadas e repletas de belas reflexões de sapiência, pelas quais nos tornamos não mais eloquentes e sim mais sábios, e que nos ensinam não a falar bem e sim a bem agir" (MONTAIGNE, 2002, Livro I, 40, p. 375). Ver também Méniel (2003).

3 As imagens do Renascimento desenhadas por Nakam mostram bem o cenário cultural do período: transitoriedade, dramaticidade, precariedade. Cf. Nakan $(1985$, p. 15, 16).
} 
interior da filosofia e desta com os saberes, o mesmo ocorrendo no âmbito da nascente ciência moderna. Os Ensaios sinalizam de modo singular essa turbulência. Sobre as novas teorias, Montaigne escreve:

Assim, quando alguma doutrina nova se apresenta a nós, temos muita razão em desconfiar dela e considerar que antes que fosse produzida sua contrária estava em voga; e, assim como aquela foi derrubada por esta, no futuro poderá nascer uma terceira invenção que da mesma forma se chocará com a segunda. [...] Que chancelas têm estes aqui, que privilégio particular, para que o curso de nossa imaginação se detenha neles, e que a eles caiba por todo o tempo futuro a posse de nossa crença? Eles não estão mais isentos de ser expulsos do que o estavam seus antecessores (MONTAIGNE, 2000, Livro II, 12, p. 356-357).

Montaigne responde ao seu tempo (e a si mesmo) com o espelho do ceticismo, cuja imagem, além de refletir a precariedade da condição humana, expressa na crítica à razão em sua tentativa de se acercar de verdades universais, é acrescida pela constatação da miséria humana, tópica de raiz cristã subvertida ao crivo de uma razão minorada:

Será possível imaginar algo tão ridículo quanto essa miserável e insignificante criatura que nem sequer é senhora de si, exposta às agressões de todas as coisas, dizer-se senhora e imperatriz do universo, do qual não está em seu poder conhecer a mínima parte, quanto mais comandá-la? E o privilégio que ele se atribui, de nesta grande construção ser o único a ter capacidade para conhecer-lhe a beleza das peças, o único que pode render graças por ela ao arquiteto e fazer a conta da receita e da despesa do mundo, quem lhe chancelou esse privilégio? Que ele nos mostre as cre- 
denciais desse belo e grande cargo! (MONTAIGNE, 2000, Livro II, 12, p. 177).

Opera-se, então, um deslocamento: uma vez estabelecida a fragilidade do conhecimento na dimensão epistemológica, cabe inspecionar as credenciais dos saberes e da própria filosofia quanto à utilidade na prática e na vida moral ${ }^{4}$.

Nas leituras senequianas de Montaigne não há uma adesão linear ou mesmo uma justaposição isenta de altercações. Pontos de confluência podem ser depreendidos no afastamento de ambos do "dogmatismo moral estoico"; e há, na outra ponta, a crítica de Montaigne ao ideal estoico de homem sábio ${ }^{5}$, como exposta no capítulo "Da crueldade", Livro II dos Ensaios, na qual a censura aos que entendem a virtude como luta e provação é também dirigida a "alguns filósofos" das escolas epicurista e estoica: “[A] [...] há vários que julgaram que não era suficiente ter a alma bem assentada, bem ajustada e bem disposta para a virtude [...] mas que era preciso também procurar as ocasiões de pôr isso à prova” (MONTAIGNE, 2000, p. 137) .

Acompanhando de perto as digressões de Sêneca sobre os estudos liberais, Montaigne, igualmente, considera-os secundários, de pouca ou nenhuma contribuição para a trajetória rumo à conduta moral. Além disso, os desdobramentos implicados no tema da utilidade dos saberes não ficam imunes

\footnotetext{
${ }^{4}$ As passagens, entre muitas, nas quais podemos observar a crítica aos saberes e sua utilidade podem ser aferidas no capítulo 12 do Livro II, ou no capítulo 12 do Livro III dos Ensaios.

${ }^{5}$ Cf. Eva (1999, p. 13, 14). Ver também: Merleau-Ponty (1991, p. 221ss).

${ }^{6}$ Nos Ensaios, as letras A, B e C entre colchetes designam as passagens que Montaigne acrescentou aos capítulos já publicados: 'A', da primeira edição, em 1580; 'B', segunda edição, em 1588; e 'C', edição póstuma de 1595, segundo o manuscrito de Bordeaux (exemplar da segunda edição dos Ensaios com novos acréscimos escritos por Montaigne, encontrado após a morte).
} 
ao procedimento da crítica cética à vaidade da razão e, menos ainda, à inquirição sobre o efetivo potencial das artes liberais em proporcionar parâmetros para o ajuizamento prático.

Nesta mesma tópica da utilidade dos saberes, temos também a importante questão em torno da prevalência do estudo da filosofia, entendida como percurso de acesso à virtude. Ali encontramos uma segunda dobra: enquanto em Sêneca a filosofia e a vida virtuosa se consagram como promovedoras da constância, em Montaigne nada é capaz de retirar em definitivo o homem de sua fluidez e movimento, nem mesmo a sabedoria filosófica. Ao assim proceder, a abordagem ética de Montaigne se distancia da busca senequiana de estabilidade e constância no agir (SÊNECA, 2009, Cartas 20, 34 e 69) e inventa o projeto de autoconhecimento vinculado à experiência pessoal e a uma adesão crítica e moderada, segundo as conveniências, aos usos e aos costumes. A apropriação de Sêneca, ao final, não deixa de ser tomada como referência significativa, porém, não ultrapassa a maneira típica dos embates travados ao longo dos Ensaios, sorvendo os "humores" dos antigos sem deixar de ombreá-los com vistas a compor uma mistura própria $^{7}$. Uma boa medida das impressões de Montaigne acerca

\footnotetext{
7 Cf. Carneiro: "Perante os antigos, Montaigne se porta como um leitor humanista na melhor versão, curioso e algo reverente em relação a um cânone pagão renovado, mas estimulado a produzir comentários pessoais aos textos, interligando passagens literárias e reflexões morais, comparando-as entre si e estabelecendo-as como parâmetro na avaliação de eventos modernos e de sua própria conduta moral e intelectual [...]. Mais propenso a explorar o potencial perturbador dos textos do que a conciliar suas contradições, ou a acomodá-los, domesticando-os, à moral cristã e à tradição escolar, os Ensaios se mostram, primordialmente, como o registro pessoal e mesmo idiossincrático de uma experiência de perplexidades, simultaneamente crítica e autocrítica - de onde, costuma-se dizer, vem a importância de seu contato com o pirronismo. A prática da leitura humanista é assim reorientada no sentido de avivar as aporias e os estranhamentos produzidos por um exercício de julgamento que parte dos textos mas vai além deles. Procedimento decisivo
} 
da leitura de Sêneca é esclarecida a partir das comparações que estabelece entre este e Plutarco: "[A] Sêneca é cheio de tiradas e argúcias; Plutarco, de coisas. Aquele inflama-vos mais e vos convence; este vos contenta mais e vos satisfaz melhor. [B] este nos guia; o outro nos impele" (MONTAIGNE, 2000, Livro II, 10, p. 123); e também é, entre tantas mais, uma apropriação a integrar parte da matéria-prima a ser digerida e transformada para a elaboração de um éthos pessoal (SCORALICK, 2013).

\section{Os estudos liberais e o ajuizamento moral}

Primeiramente, convém notar a forte vinculação que Sêneca estabelece entre os estudos das artes liberais e os potenciais ganhos que elas podem trazer para a ação. Ter clareza nesta vinculação é fator decisivo para os estudos, já que a utilidade de cada saber e a correspondente dedicação a lhe ser agenciada decorre da gradação entre o saber e sua utilidade.

Trata-se menos de aguçar o "engenho", substrato derivado da dedicação aos estudos liberais, e mais de cultivar a alma por meio das implicações morais retiradas dos estudos, sobretudo da filosofia (SÊNECA, 2009, Carta 89, p. 437). Por sua vez, o cultivo da alma em direção à sabedoria é antecipado pela advertência de que "o saber não se obtém por obra

na avaliação de autores (contrapondo Virgílio e Lucrécio, Plutarco e Sêneca, Tito Lívio e Tácito, etc.), o iudicium comparativo será arma, tão contundente quanto afiada, também na abordagem de assuntos "não literários", temas espinhosos como a fé religiosa, a sexualidade ou a própria natureza "instável" do eu racional em um procedimento que desestabiliza, por contágio, todo um sistema de crenças paralisantes e categorias simplificadoras [...]. Advertindo-nos que limitará sua atividade de escrita ao propósito restrito de se dedicar à criação de um ethos privado, ele pode tomar distância dos saberes instituídos e se pronunciar em nome próprio" (CARNEIRO, 2011, p. 115-116). 
do acaso. [...] a virtude, essa, não virá ter contigo! Não é sem custo, sem grandes esforços, que chegamos a conhecê-la [...]" (Idem, Carta 76, p. 312). Para ser bom, é preciso instruir a alma, exercitá-la, cultivá-la, porquanto a virtude não é inata (Ibidem, Carta 90), requer, antes, empenho crescente a começar pela compreensão de preceitos de aplicação imediata e cuja utilidade se amolda em auxílios circunstanciais: "Procura recolher, isso sim, preceitos que te sejam úteis, frases e lições cheias de sentido que possas desde logo pôr em prática. Façamos com que nosso estudo transforme as palavras em ato" (Ibid., Carta 108, p. 602). Esta primeira tarefa concerne a uma parenética (SÊNECA, 2009, Carta 94, p. 480) e, conforme avançam os estudos, se abre o acesso aos fundamentos éticos, a decreta (Idem, Carta 95, p. 505), estes sim, imprescindíveis ao cultivo da alma.

O movimento inicial da Carta 88 estabelece o lugar das artes liberais no conjunto dos estudos: não são bens autênticos; na verdade, são úteis por servirem de subsídio e exercitação preparatória para os estudos mais avançados (aqueles que realmente tornarão o homem livre ${ }^{8}$ ), por isso, aos estudos liberais se dispõe um período curto de tempo. Tais artes "não guiam o espírito até à virtude, mas facilitam-lhe o trajeto" (SÊNECA, 2009, Carta 88, p. 422). Na sequência, Sêneca discorre sobre cada uma das artes, situando-as em função de suas finalidades específicas. A primeira delas é a gramática: “[...] ocupa-se do estudo da linguagem: se pretender espraiar-se

\footnotetext{
${ }^{8}$ Segundo Sêneca (2009, Carta 51, p. 174), a liberdade consiste "Em não ser escravo de nada, de nenhuma necessidade, de nenhum acaso, em lutar de igual para igual com a fortuna". E na Carta 75 (SÊNECA, 2009, p. 301): "Queres saber em que consiste a liberdade? Em não temermos nem os homens nem os deuses; em não desejarmos nada que seja imoral ou excessivo; em termos o maior domínio sobre nós próprios [...]".
} 
mais longe ocupar-se-á da explicação de textos, e se chegar aos seus extremos limites abordará a poética" (Idem, Carta 88, p. 415-416). Porém, são conhecimentos que não contribuem para o caráter: "Em que é que estes assuntos aplanam a via para a virtude? [...] em que é que isto contribui para nos livrar do medo, nos libertar do desejo, nos refrear as paixões?" (Ibidem, Carta 88, p. 416). O mesmo viés argumentativo percorre as outras artes e os ofícios delas decorrentes: os músicos sabem sobre a harmonia dos sons; mas o que importa, na verdade, é a harmonia do espírito consigo mesmo, "ter consonância nas minhas ideias". (Ibid., Carta 88, p. 418). O geômetra trata com os números e as medições, conhecimento importante para o controle dos bens patrimoniais, mas "Que notável técnica: sabes medir círculos, [...] sabes determinar as distâncias entres os astros. [...] Sabes o que é uma linha reta: de que te serve isso se não souberes andar na vida com retidão?” (SÊNECA, 2009, Carta 88, p. 419). Para ficarmos com uma última notação, vejamos o astrólogo:

Que me adianta este saber? Ficar preocupado cada vez que Saturno e Marte estão em oposição, ou Mercúrio entra em ocaso com Saturno ainda acima do horizonte? [...] Se são causa de tudo quanto acontece, em que nos beneficia o conhecimento de algo que é imutável? Se são indícios, que nos adianta prever aquilo a que não podemos escapar? (SÊNECA, 2009, Carta 88, p. 419-420).

Enfim, a matiz recorrente nas passagens corrobora a depreciação da utilidade própria de cada uma das artes, seja em seu objeto ou por sua finalidade. Algo análogo se repete nos comentários sobre a retórica e a lógica. $\mathrm{Na}$ Carta 48 , e mais especificamente na Carta 75, encontramos as posições de 
Sêneca em relação a essas duas matérias. Quanto aos silogismos capciosos, não passam de "infantilidades", nada podem oferecer sobre as deliberações necessárias à vida. Em chiste, Sêneca deixa claro o valor atribuído aos raciocínios sofísticos:

Rato é um dissílabo; ora o rato rói o queijo; logo um dissílabo rói o queijo. Imagina que eu sou incapaz de resolver esta questão: que perigo me sobrevém desta minha incapacidade? Que prejuízo? Se calhar tenho de acautelar-me, não vá dar com a ratoeira cheia de sílabas, ou não vá algum livro, se eu me descuidar, comer-me o queijo todo! (SÊNECA, 2009, Carta 48, p. 163).

O teor da crítica à retórica é mais moderado, e novamente ali a orientação prática é o fator determinante para a utilidade; ações e palavras devem estar em sintonia, porém, a primazia recai sobre as primeiras:

As nossas palavras não visam o prazer literário, mas sim a pertinência. Se a eloquência surge, por assim dizer, naturalmente, sem esforço, ou quase, deixemo-la acompanhar as mais nobres ações e realçar, não a sua presença, mas a ação em si (Idem, Carta 75, p. 306)9 .

Montaigne segue uma linha similar à de Sêneca no que diz respeito aos saberes: argumentos articulados a partir da relação entre utilidade e ética e acompanhados de certa dose de ironia ${ }^{10}$. As críticas mais desfavoráveis são direcionadas para a gramática, a retórica e para a dialética, artes que dispunham de graus variados de prestígio entre os humanistas,

\footnotetext{
$9 \mathrm{Na}$ Carta 111, 1, 2, 3 encontramos a crítica aos cauillationes (sophisma), os discursos vazios de utilidade prática e cheios de sutilezas capciosas.

${ }^{10}$ Cf. Montaigne (2000, Livro II, 12. p. 230, 231); (2002, Livro I, 26. p. 239).
} 
mas sempre consideradas a base maior dos studia humanitatis. São inúmeras as passagens dos Ensaios, muitas delas localizadas na tradicional tópica das palavras e das coisas, que registram a depreciação da gramática e da retórica no quadro dos saberes ${ }^{11}$. Montaigne se mantém na companhia de Sêneca - a matéria, a simplicidade na expressão e, principalmente, a ação têm prevalência sobre a palavra - mesmo quando atinge o ponto central de sua crítica: a utilização desmedida da dialética e as prerrogativas concedidas à eloquência resvalam num jogo vazio de palavras, em nada contribuem para o efetivo sentido das coisas e para a vida prática. Sobre a sofística, por exemplo, nitidamente temos um correlato ao disposto por Sêneca na acusação de se tratar de um arremedo de palavras que beiram a criancice: "[C] Vai brincar desses malabarismos [argumentos sofísticos] com as crianças, e não desvies para isso os pensamentos sérios de um homem adulto" (MONTAIGNE, 2002, Livro I, 26, p. 256).

Como se evidencia, em Montaigne, os estudos liberais também não são prioritários e, desviando um pouco da rota senequiana, menos ainda são preparatórios. A prioridade e a ênfase nos estudos permanecem incondicionalmente consignadas à utilidade no campo ético:

[A] Depois que lhe tiverem dito o que é próprio para fazê-lo mais sábio e melhor, falar-lhe-ão sobre o que é a lógica, a física, a geometria, a retórica; e a ciência que escolher, tendo já o discernimento formado, ele [o jovem] muito em breve a dominará (MONTAIGNE, 2002, Livro 1, 26, p. 160).

${ }_{11}$ Ver especialmente o capítulo Da arte da conversação, Ensaios, Livro III, 8. 
Há, portanto, entre Montaigne e Sêneca a concordância em relação à pouca utilidade dos estudos liberais; contudo, Montaigne propõe uma alteração na ordem dos estudos, a preparação para a vida moral não exige preliminares ou caminho a ser facilitado por exercícios introdutórios.

\section{As sutilezas intelectuais}

Um derivativo importante da discussão sobre a utilidade dos saberes tem lugar na tópica das sutilezas intelectuais, particularmente na oposição entre saber muito sobre muitas coisas e saber o indispensável para se tornar um homem de bem. Advém deste argumento a oposição entre erudição e sabedoria, a qual, em Sêneca, se estende, ainda, na crítica à escola (SÊNECA, 2009, Carta 76, 4) e aos falsos filósofos que transformam a filosofia em filologia e em verbalismo (Idem, Cartas 7 e 108); e, em Montaigne, está expressa na mordaz crítica ao pedante e seu modo de instrução livresca (MONTAIGNE, 2002, Livro I, 25). Por agora, no âmbito dessa mesma tópica, fiquemos com uma de suas variações - o papel da curiosidade - aqui tratada nos termos da curiosidade excessiva, em Sêneca, e da curiosidade mal direcionada, em Montaigne.

Na Carta 108, Lucílio é aconselhado a moderar sua "ardente" curiosidade pelo conhecimento. $\mathrm{O}$ mote da recomendação reside na necessidade de se conciliar a preparação já adquirida (habilidade instalada) com o que é possível avançar nos conhecimentos a partir dela, o que impõe uma necessária e paciente ordenação das matérias a ser passo a passo estudadas até se atingir o ápice do saber. $\mathrm{O}$ apressado na marcha rumo à sabedoria ingenuamente se encanta com máximas, 
preceitos, discursos, mas, nada disso, efetivamente, penetra-lhe o espírito; tudo que o atinge permanece numa superficialidade facilmente turvada por influências diversas quase sempre inúteis para a prática moral. Em poucas palavras, o afogadilho nos estudos é típico dos hóspedes da filosofia, mas não de seus verdadeiros discípulos (SÊNECA, 2009, Carta 108, p. 592).

O núcleo da questão da sutileza intelectual reside no entendimento de que todas as matérias que não atingem o cerne da ética, não passam de sutilezas a abarrotar o espírito com assuntos periféricos e, por isso, não devem ocupar ali espaço além do extremamente necessário ${ }^{12}$. As sutilezas estão diretamente vinculadas às artes, às firulas gramaticais, aos sofismas, às novas teorias; enfim, deixar-se levar por uma curiosidade excessiva nos estudos liberais só tende a aumentar o espaço ocupado pelo supérfluo, gastar tempo e desgastar a memória:

Mede a duração de tua vida: não cabe lá muita coisa. Eu estou falando dos estudos liberais; mas mesmo os filósofos, quanta superficialidade, quanta coisa inútil neles encontramos! [...]. Podes atirar tudo isso para o meio do armazém de superficialidades que são os estudos liberais (SÊNECA, 2009, Carta 88, p. 428, 429).

Com Montaigne sobrevém algo semelhante: tempo demais dedicado aos estudos e matérias que acrescentam pouco ao exercício do julgamento. O pedante é o exemplo maior de quem se agarra na erudição inútil e deixa o principal de lado.

\footnotetext{
12 Sêneca aconselha: "Subtrai-te quanto possível a essas sutilezas, a essas argúcias da filosofia. À boa formação do espírito convém a clareza e a simplicidade. Ainda que nos restasse muito tempo de vida, haveria que poupá-lo com cuidado, de modo a bastar o indispensável. Grande estultícia seria aprender inutilidades apesar de uma tão grande escassez de tempo!” (SÊNECA, 2009, Carta 48, p. 165).
} 
Mas a curiosidade não é apenas negatividade; quando bem direcionada, torna-se eficaz e diligente na compreensão das variadas opiniões e da diversidade dos modos de vida, ampliando o cardápio de que se vale a matéria-prima do ajuizamento; tais serviços transformam uma curiosidade obstinada ou fútil em uma "honesta curiosidade" (MONTAIGNE, 2002, Livro I, 26. p. 233). O interesse pelo conhecimento alia-se, então, a uma curiosidade de boa-fé, ciente das imperfeições e fraquezas dos saberes e das filosofias (DELEGUE, 1998, p. 104-110). Por outro lado, a curiosidade imoderada, que desenfreadamente busca por um saber acima das possibilidades humanas ou de pouca utilidade para as reais necessidades, resulta em consequências que arrastam o espírito para o dogmatismo e a vaidade. A crítica à curiosidade insaciável pode ser encontrada no Livro II, capítulo 12; ali a curiosidade é adicionada ao rol das paixões e infortúnios humanos:

[A] [...] temos como quinhão nosso a inconstância, a irresolução, a incerteza, a dor, a superstição, a inquietação das coisas por vir (mesmo depois da nossa vida), a ambição, a avareza, o ciúme, a inveja, os apetites desregrados, loucos e indomáveis, a guerra, a mentira, a deslealdade, a difamação e a curiosidade. Por certo pagamos extraordinariamente caro por essa bela razão de que nos vangloriamos e essa capacidade de julgar e conhecer, se as adquirimos à custa desse número infinito de paixões a que estamos incessantemente expostos (MONTAIGNE, 2000, Livro II, 12, p. 229-230).

À curiosidade insaciável, parceira da busca presunçosa do saber, contrapõe-se, assim, uma diligência "honesta", que colhe na diversidade dos homens variados elementos a serem, similarmente ao que é sugerido na metáfora das abelhas, tão 
cara a Sêneca e a Montaigne, transformados em matéria da investigação ética.

\section{A utilidade da filosofia}

Após a apresentação das artes e a constatação de que suas propriedades e finalidades nada dizem respeito à esfera moral, Sêneca retoma a classificação de Posidônio sobre os tipos de arte - as vulgares, as recreativas, as educativas e as liberais - sendo apenas as últimas, em seu "domínio próprio", aptas a proporcionar algum tipo de serviço para a filosofia (Carta 88). No desdobramento deste argumento, em especial a objeção de que as artes possam vir a se constituir em componentes da filosofia, mantendo com ela uma relação de pertencimento, Sêneca responde negativamente, repudiando a possibilidade de alçá-las à condição de parte da filosofia. A justificativa desta posição reside no argumento de que a filosofia tem a exclusividade de engendrar sua doutrina de forma independente, não sendo subsidiária de nenhum outro saber. A discussão desencadeada sobre a contribuição das artes faz retornar, então, a alegação de que as artes liberais, mesmo sem nada contribuir para o alcance da virtude, merecem ser estudadas. Esta objeção se detém na intrigante possibilidade de conciliar a proposição da inutilidade das artes liberais para o alcance da virtude e seu papel propedêutico aos estudos avançados que, justamente, são os que conduzem à virtude. Tal polêmica parece se resolver através de dois argumentos: o primeiro sobre a noção de "contributo", e o segundo relacionado às exigências intelectuais da própria filosofia.

O contributo é sempre algo dispensável, não é fundamento, não é essencial (SÊNECA, 2009, Carta 88, p. 425); 
corrobora-se, assim, a possibilidade de atingir a sabedoria sem as artes. A contribuição de cada uma delas não está em ensinar a virtude, no entanto, ao ensinar o que lhes é próprio e, desde que acomodadas em certos limites, promovem exercícios que favorecem e aguçam o "intelecto" e o "engenho", mas em nada tocam no cultivo da alma.

Para o cultivo da alma, é preciso ir à filosofia (Idem, Carta 108, p. 598-599), elevar-se a uma razão superior ${ }^{13}$. O engenho, razão de tipo inferior, é da esfera da habilidade técnica (Ibidem, Carta 90, p. 447), seu alinhamento está junto do artifício e de tudo que está irmanado ao supérfluo. Em seus procedimentos e produtos, o engenho não avalia o quão são bons ou lesivos, se úteis ou inúteis: "A civilização do luxo é um desvio em relação à natureza: dia-a-dia cria novas necessidades, que aumentam de época para época; o engenho está ao serviço do vício!" (SÊNECA, 2009, Carta 90, p. 445). Em contrapartida, a razão superior, única capaz de discernir acertadamente na esfera moral, não se faz presente em nenhuma das artes (manuais ou liberais); estas estão limitadas aos próprios âmbitos de competência, seus modos de operação, efetivamente, não dizem respeito nem à verdade, nem às consequências acerca das coisas e do agir: "Um operário não precisa investigar qual a origem ou utilidade do seu trabalho [...]" (Idem, Carta 95, p. 520). Podemos tomar como definitiva a passagem da Carta 85 , na qual o contexto da finalidade de cada saber determina sua hierarquia e esfera de atuação:

\footnotetext{
${ }^{13} \mathrm{Na}$ Carta 76, Sêneca afirma que quando a razão se realiza inteiramente, alça o homem à plenitude: “[...] o homem torna-se admirável e atinge sua finalidade natural quando leva a razão à perfeição máxima. À razão perfeita chamamos a virtude, a qual é também o bem moral" (SÊNECA, 2019, p. 314).
} 
Tudo isso estaria certo se porventura a condição de piloto fosse idêntica à condição do sábio. $\mathrm{O}$ objetivo que norteia o mesmo modo de vida do sábio não consiste em levar a cabo de qualquer maneira tudo o que empreende, mas sim em fazer tudo com retidão; em contrapartida o objetivo do piloto é levar o navio ao porto seja como for. As artes são meros auxiliares, e devem prestar os serviços que oferecem, ao passo que a sapiência tem por função governar e dirigir. Na vida as artes servem, a sapiência ordena! (SÊNECA, 2009, Carta 85, p. 392-393).

Em Montaigne, associada às críticas ao propósito da presunção humana de tudo querer e acreditar poder conhecer, decorre a necessidade de se avaliar a extensão da fragilidade dos saberes para se equacionar, posteriormente, o crédito a ser conferido às suas asserções e ao uso que proporcionam. O resultado desta avaliação conduz a filosofia ao topo dos saberes, pois é ela, e não as artes, que cumpre a tarefa da orientação moral (MONTAIGNE, 2002, Livro I, 26). O saber de nada vale se simplesmente estiver pendurado na alma como um acessório e só se tornará efetivamente útil se acompanhado do discernimento, porquanto sozinho não auxilia na condução do pensamento e menos ainda impele à ação: “[C] [...] os exemplos nos ensinam que o estudo das ciências mais amolece e efemina os ânimos do que os torna firmes e aguerridos" (Idem, Livro I, 25, p. 214). O estudo das artes, quando sem o firme discernimento, afora não contribuir diretamente para a sagesse, provoca uma falsa impressão de sabedoria e eficiência; falsa porque não lhe é próprio, em razão do seu uso adequado, depender "de entendimento e de consciência", os quais não pode oferecer por estar fora de sua competência. A erudição resultante da dedicação às artes pode estar irmanada da 
vaidade, mas não da inteligência e da utilidade (Ibidem, Livro I, 25, p. 211).

Sobretudo, a utilidade da filosofia, seja em Sêneca, seja em Montaigne, se manifesta na sua exclusividade de interferir, quase imediatamente, na conduta moral, e, de modo mais prolongado e contínuo, no percurso que conduz até a sabedoria.

Nas Cartas, os aconselhamentos a Lucílio, apesar de se iniciarem com preceitos ${ }^{14}$, buscam ir além, propondo o cultivo da alma pelo aprofundamento das questões pertinentes à filosofia. Entendida como uma terapêutica da alma, a filosofia se volta para a vida prática ${ }^{15}$; mais que mera especulação, configura uma arte de viver exigente que solicita ócio e exercitação; para além do seu teor contemplativo, seu ofício é a ação.

A filosofia não é uma habilidade para exibir em público, não se destina a servir de espetáculo; a filosofia não consiste em palavras, mas em ações. O seu fim não consiste em fazer-nos passar o tempo com alguma distração, nem em libertar o ócio do tédio. O objetivo da filosofia consiste em dar forma e estrutura à nossa alma, em ensinar-nos um rumo na vida, em orientar os nossos atos, em apontar-nos o que devemos fazer ou pôr de lado, em sentar-se ao leme e fixar a rota de quem flutua à deriva entre escolhos. Sem ela ninguém pode viver sem temor, ninguém pode viver em segurança (SÊNECA, 2009, Carta 16, p. 55).

A filosofia tem por objetivo acercar-se das verdades que dizem respeito ao homem, abarcando o divino e o humano;

\footnotetext{
${ }_{14}$ Quanto à utilidade dos preceitos na constituição da conduta, ver Carta 94, especialmente 21, 30, 31, p. 485.

15 "Vou compondo alguma coisa que lhe possa vir a ser útil; passo ao papel alguns conselhos, salutares como as receitas dos remédios úteis [...]" (SÊNECA, 2009, Carta 8, p. 18, 19).
} 
suas lições estão disponíveis para todos, mas alcançá-las requer esforço (Idem, Carta 90, p. 439). Por isso, a recursiva preocupação senequiana com o tempo desperdiçado com estudos irrelevantes, com os minutos deixados na indolência ou na inutilidade (Ibidem, Carta 1). A jornada filosófica ${ }^{16}$ que conduz à sabedoria exige o ócio útil, aqui traduzido na tentativa de viver firme e moderadamente em seus propósitos (Carta $55,4,5$, p. 188). Porém, somente o sábio ${ }^{17}$, aquele que atingiu a plenitude da sabedoria, é capaz de se manter constante e inabalável aos golpes da fortuna e aos dissabores da vida, se preservando em seu recolhimento reflexivo. Quanto ao homem comum (e todos são, apesar da gradação resultante da maior ou menor aproximação da filosofia), deve buscar, pelo menos, a constância nos estudos filosóficos (Ibid., Carta 72, p. 286). Quanto ao sábio, depositário do completo entendimento da filosofia, e justamente por este motivo, suas principais características são a constância da vontade e a consonância entre suas palavras e seus atos, o que lhe permite estar em perene estado de contentamento.

A alma do sábio é semelhante à do mundo supralunar: uma perpétua serenidade. Aqui tens mais um motivo para desejares a sabedoria: alcançar um estado a que nunca falta a alegria. Uma alegria assim só pode vir da consciência das próprias virtudes: apenas o homem forte, o homem justo, o homem moderado pode ter alegrias (SÊNECA, 2009, Carta 59, p. 215).

\footnotetext{
16 Sobre as divisões da filosofia e a polêmica que Sêneca estabelece com os filósofos, ver Carta 89, p. 431ss; e Carta 94, p. 479ss.

17 Segundo Gazolla (1999, p. 71), o sábio estoico sintetiza uma imagem persuasiva de guia, porém não atingível. A imagem do sábio senequiano é um modelo a ser perseguido, está no plano ideal e desempenha o papel de mestre exemplar. Sócrates e Catão são referências nesse sentido. Na Carta 42, 1, a figura do sábio tem por referência a fênix; entre o surgimento de uma e outra são guardados grandes intervalos de tempo.
} 
Mas o homem comum não está totalmente desabrigado da sabedoria e dos ganhos que ela oferece, se insistir nos estudos filosóficos. A diferença entre o sábio e aquele que caminha em direção à sabedoria (o proficiente ${ }^{18}$ ) é, justamente, a determinação em se manter constante e estável:

O que é fixo e bem agarrado ao chão não erra ao acaso [...]. A diferença entre ambos [o sábio e o proficiente] reside em que o segundo, embora sem mudar de posição, oscila na sua base, enquanto o primeiro nem sequer oscila (SÊNECA, 2009, Carta 35, p. 127).

$\mathrm{Na}$ Carta 75, são apresentados os degraus de aproximação da sabedoria, cujo matiz tem na constância e na estabilidade os critérios de medida.

Com Montaigne, a filosofia recebe o proeminente status de saber mais importante no conjunto dos studia humanitatis e das artes estudadas pelos humanistas. A prevalência da filosofia, contudo, só se faz possível após a crítica empreendida ao modo como é rotineiramente concebida e ensinada por seus contemporâneos: dela é preciso afastar todos os dogmatismos e todos os "ergotismos" que dificultam o acesso a uma verdadeira filosofia prática (MONTAIGNE, 2002, Livro I, 26, p. 240). Concluído este primeiro movimento, Montaigne recorre a Epicuro para confirmar o argumento de que a filosofia convém para todos os que estão em busca da virtude:

\footnotetext{
18 "Segundo o estoicismo antigo, os homens estavam divididos em duas classes somente, a dos sapientes (sábios) e a dos stulti (insensatos). Uma categoria intermediária, a dos proficientes, pode ter se originado durante o estoicismo médio. Estes, embora não sapientes, eram os que haviam se iniciado no caminho para a sapientia e também se encontravam separados em classes, de acordo com as quais se achavam mais ou menos próximos da sabedoria" (BREGALDA, 2006, p. 39).
} 
[C] É o que diz Epicuro no começo de sua carta a Meneceu: "Nem o mais jovem se recuse a filosofar, nem o mais velho se canse disso". Quem age diferentemente parece dizer ou que ainda não é tempo de viver venturosamente ou que já não é tempo (Idem, Livro I, 26, p. 245$)^{19}$.

O próprio da filosofia é sua expertise no tratamento dos assuntos da alma e do corpo, daquilo que faz sofrer ou causa prazer, e seus benefícios incidem sobre a moderação dos afetos, adequando-os ao que é natural de cada um. Ela nos "serve diretamente e profissionalmente" (MONTAIGNE, 2002, Livro I, 26, p. 237-238), numa fruição sem desvio entre seus ensinamentos e seus resultados, agindo sobre a exercitação de nos conhecermos internamente e exercermos sobre nós uma autojurisdição; assim fazendo, nos faz livre por adequar os prazeres naturais a uma vida virtuosa ${ }^{20}$.

Das concepções de filosofia de Sêneca e de Montaigne podemos inferir aproximações e distanciamentos. A filosofia, como estudo prioritário e como lugar da reflexão moral, consiste o ponto comum evidente. E de que filosofia ambos estão a falar? Para Sêneca, obviamente, os contornos tradicionais do estoicismo, mesmo sombreados, se fazem presentes, são verdades fundantes. Montaigne descarta a possibilidade de adesão a uma tendência filosófica (lembremos do crivo cético); todas as filosofias, e cada uma a seu modo, podem ter utilidade conforme as solicitações das circunstâncias, não havendo

\footnotetext{
19 Epicuro (1980, p. 13) reafirma a utilidade da filosofia em: "Deves servir à filosofia para que possas alcançar a verdadeira felicidade”. Ver também Epicuro (2013). 20 "[B] A filosofia não luta contra as voluptuosidades naturais, contando que lhes seja juntada a justa medida, [C] e prega a moderação nelas, não a fuga: [B] a força de sua resistência volta-se contra as estranhas e bastardas" (MONTAIGNE, 2001, Livro III, 5, p. 160).
} 
qualquer tipo de preocupação em construir elos de ligação ou pontos de conciliação entre elas.

Sobretudo a regra da constância, exemplar na figura do sábio senequiano, concentra o âmago do distanciamento entre Sêneca e Montaigne. A constância é a marca do sábio, ela revela sua determinação em permanecer inabalável seja pelas paixões e infortúnios, seja pelo destino. O sábio, mesmo que pertencente ao plano ideal, não deixa de constituir o modelo normativo a ser perseguido por quem se dispõe, apesar de ciente de nunca alcançar plenamente, superar a vida de superficialidade, de vícios e das falsas alegrias do vulgo. Para Montaigne, o homem é inconstante, a sabedoria proporcionada pela filosofia consiste, justamente, em aprender a transitar na inconstância das paixões; não existindo a possibilidade de extirpá-las, melhor aprender a regrá-las através da moderação auferida no contato com a filosofia, tarefa, contudo, com poucas chances de sucesso.

[B] O mundo não é mais que um perene movimento. Nele todas as coisas se movem sem cessar [...] A própria constância não é outra coisa senão um movimento mais lânguido. Não consigo fixar meu objeto [o próprio eu]. Ele vai confuso e cambaleante, com uma embriaguez natural. Tomo-o nesse ponto, como ele é no instante em que dele me ocupo. Não retrato o ser. Retrato a passagem. [...]. Daqui a pouco poderei mudar, não apenas de fortuna mas também de intenção. Este é um registro de acontecimentos diversos e mutáveis e de pensamentos indecisos, e se calhar, opostos [...]. Se minha alma pudesse firmar-se, eu não me ensaiaria: decidir-me-ia [...] (MONTAIGNE, 2001, Livro III, 2, p. 27-28). 
As tensões de toda ordem que agitam o mundo renascentista e a própria inspeção interna de Montaigne não são suficientes para constrangê-lo ao imobilismo ou ao relativismo moral, ao contrário, provocam uma maneira peculiar de operar na dimensão prática que se resolve na articulação de critérios distintos para o exame do conhecimento e para o tratamento da ação ${ }^{21}$ : para o conhecimento vale a prerrogativa pirrônica; para a prática, valem os ajuizamentos circunstanciados "de uma cabeça bem feita!" (Idem, Livro III, 13, p. 435). Dito de outra forma, o vértice cético de suas posições não impede uma elaboração moral que empresta da tradição filosófica a matéria a ser remoldada. Em que pese, de um lado, a presença incisiva do ceticismo e as fragilidades teóricas, religiosas e políticas imanentes ao seu tempo, de outro, é do ponto de vista da utilidade que os saberes são avaliados, ou melhor, o critério advém da participação dos conhecimentos na vida prática. No conjunto das discussões sobre os usos dos saberes, Sêneca, nas suas recomendações a Lucílio, constrói o vínculo entre a ética e o conhecimento; Montaigne, no que poderíamos caracterizar como uma leitura num só tempo aproximativa e pouco escolar das lições senequianas sobre os estudos liberais, rearranja a ordem dos saberes tradicionalmente observada nos studia humanitatis e os projeta para a periferia da esfera moral.

\footnotetext{
${ }^{21}$ Segundo Eva (2012, p. 397-419), Montaigne estabelece critérios distintos para a ação e para a verdade, ou seja, para a "dimensão prática e a experiência", de um lado, e para "o modo como as pretendemos conhecer", de outro. Entendemos que a base da "dimensão prática" em Montaigne circunda menos uma possível naturalização da ética e mais a ênfase sobre um apurado autoconhecimento a partir da experiência de si e da observação dos homens.
} 


\section{Referências}

BREGALDA, M. M. Sapientia e uirtus: princípios fundamentais no estoicismo de Sêneca. Dissertação. Campinas: Unicamp, 2006.

CARDOSO, S. Montaigne: uma ética para além do humanismo. O que nos faz Pensar, Cadernos do Departamento de Filosofia da PUC-Rio, RJ, n. 27, p. 257-278, maio 2010.

CARNEIRO, A. S. Exercícios espirituais e parrhesia nos Ensaios de Montaigne. In Rev. Filos., Aurora, v. 23, n. 32, 2011.

D’ANGERS, J. E. Le renouveau du stoïcisme en France au XVIe siècle et au début du XVIIe. In: Bulletin de l'Association Guillaume Budé, n. 1, 1964.

DELEGUE, Y. Montaigne et la mauvaise foi. Lécriture de la vérité. Paris: Honoré Champion, 1998.

EPICURO. Máximas Principais. Tradução de João Quartim de Moraes. São Paulo: Loyola, 2013.

Carta sobre a felicidade (a Meneceu). Tradução de Âlvaro Lorencini e Enzo Del Carratore. São Paulo: Unesp, 2002. Antologia de textos. Tradução de Agostinho da Silva, Giulio Leoni e Jaime Bruna. São Paulo: Abril Cultural, 1980.

EVA, L. A. A. Montaigne, leitor de Sexto Empírico: a crítica da filosofia moral. In: Kriterion, Belo Horizonte, n. 126, 2012.

Notas sobre a presença de Sêneca nos Essais de Montaigne. In: Educação e Filosofia, vol. 17, n. 1, 1999. 
GAZOLLA, R. O ofício do filósofo estoico: o duplo registro do discurso da Stoa. São Paulo: Loyola, 1999.

HADOT. P. La philosophie comme manière de vivre. Paris: Albin Michel, 2001.

INWOOD, B. (Org.). Os estoicos. Tradução de Paulo F. T. Ferreira. São Paulo: Ed. Odysseus, 2006.

MERLEAU-PONTY, M. Signos. Tradução de Maria Ermantina G. G. Pereira. São Paulo: Martins Fontes, 1991.

MÉNIEL, B. Léthique des épîtres morales (1598-1610). In: Bulletin de l'Association d'étude sur l'humanisme, la réforme et la renaissance, n. 57, 2003.

MONTAIGnE, M. Les Essais. Éd. Pierre Villey. Paris: PUF, 1999. v. I.

. Les Essais. Éd. Pierre Villey. Paris: PUF, 1999. v. II.

. Les Essais. Éd. Pierre Villey. Paris: PUF, 2002. v. III.

. Os Ensaios. Tradução de Rosemary C. Abílio. São Paulo: Martins Fontes, 2002. v. I.

. Os Ensaios. Tradução de Rosemary C. Abílio. São Paulo: Martins Fontes, 2000. v. II.

. Os Ensaios. Tradução de Rosemary C. Abílio. São Paulo: Martins Fontes, 2001. v. III.

NAKAM, G. «Voyage...», «Passage...» chez Montaigne. In: Bulletin de l'Association d'étude sur l'humanisme, la réforme et la renaissance, n. 21, 1985. 
SÊNECA, L. A. Cartas a Lucílio. Tradução de J. A. Segurado e Campos. Lisboa: Fundação Calouste Gulbenkian, 2009.

SILVEIRA, F. L. da; CARDOSO, I. T. Sine Radice Inutiles Rami Sunt (...): Praecepta e Decreta nas Epístolas 94 e 95 de Sêneca. In: Língua, Literatura e Ensino, vol. 4, 2009.

SCORALICK, A. Paixão, liberdade e conveniência em dois ensaios de Montaigne (Da vaidade e de poupar a própria vontade). Tese - Departamento de Filosofia da Faculdade de Filosofia, Letras e Ciências Humanas, São Paulo (FFLCH/USP), 2013.

SPANNEUT, M. Permanence de Sénèque le Philosophe. In: Bulletin de l'Association Guillaume Budé: Lettres d'humanité, n. $39,1980$.

TOURNON, A. L'Apologie de Raymond Sebond : le paradoxe et l'Essai. In: Bulletin de l'Association d'étude sur l'humanisme, la réforme et la renaissance, n. 8, 1978. 